\title{
Lues maligna in a patient with unknown HIV infection
}

\author{
Claudia Pföhler, ${ }^{1}$ Rebecca Koerner, ${ }^{1}$ Lutz von Müller, ${ }^{2}$ Thomas Vogt, ${ }^{1}$ Cornelia S.L. Müller ${ }^{1}$ \\ ${ }^{1}$ Department of Dermatology, Saarland University Hospital, Homburg/Saar, Germany; \\ Institue for Medical Microbiology and Hygiene, Saarland University Hospital, Homburg/Saar, Germany \\ Correspondence to Dr Cornelia S.L. Müller, c_mueller1977@yahoo.de
}

\section{Summary}

Lues maligna represents a rare form secondary syphilis and is also known as 'malignant syphilis' or 'ulceronodular syphilis'. This clinical entity is predominantly found in immunodeficient patients such as patients with HIV or AIDS. The patient presented here suffered from unspecific symptoms such as painful joints, headache, flu-like symptoms and a disseminated exanthema presenting with ulcerating nodules for 1 week. He further reported a 7 weeks history of painless ulcer, involving his external genitals and anus. Unsafe sexual contacts were strictly denied first, but as serological investigation could prove active syphilis and HIV infection, the patient finally stated promiscuous unprotected homosexual contacts in the past. He was treated with penicillin $\mathrm{G}$ intravenously three times daily. The unspecific flu-like symptoms disappeared quickly within several days, all skin lesions healed, partly with scars after 2 weeks.

\section{BACKGROUND}

The incidence of lues infection is rising steadily worldwide, especially in homosexual men. Lues maligna is predominantly seen in immunodeficient patients with, for

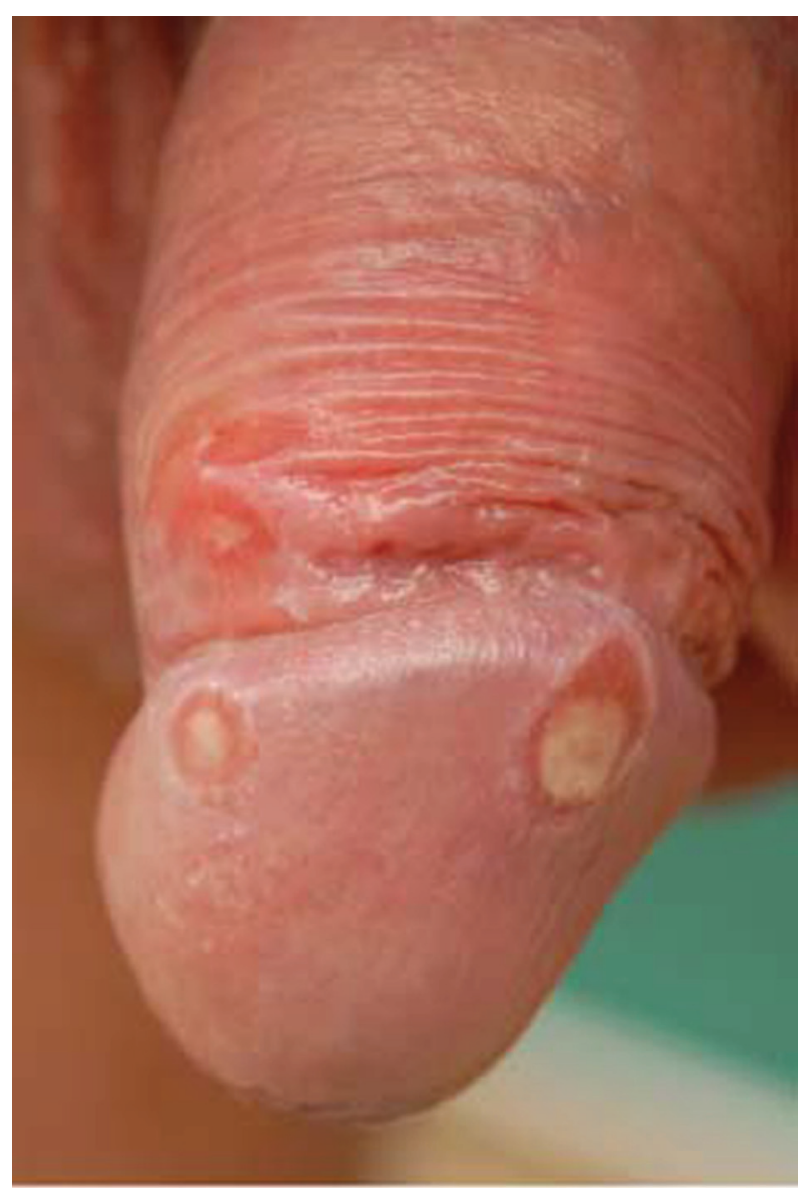

Figure 1 Multiple, fibrin-covered, painless ulcerations on the penis. example, HIV or AIDS. An ulcerating exanthema is obligatory and often accompanied by unspecific findings such as fever, fatigue, loss of appetite and painful joints. We present this case to show typical clinical signs of lues maligna and

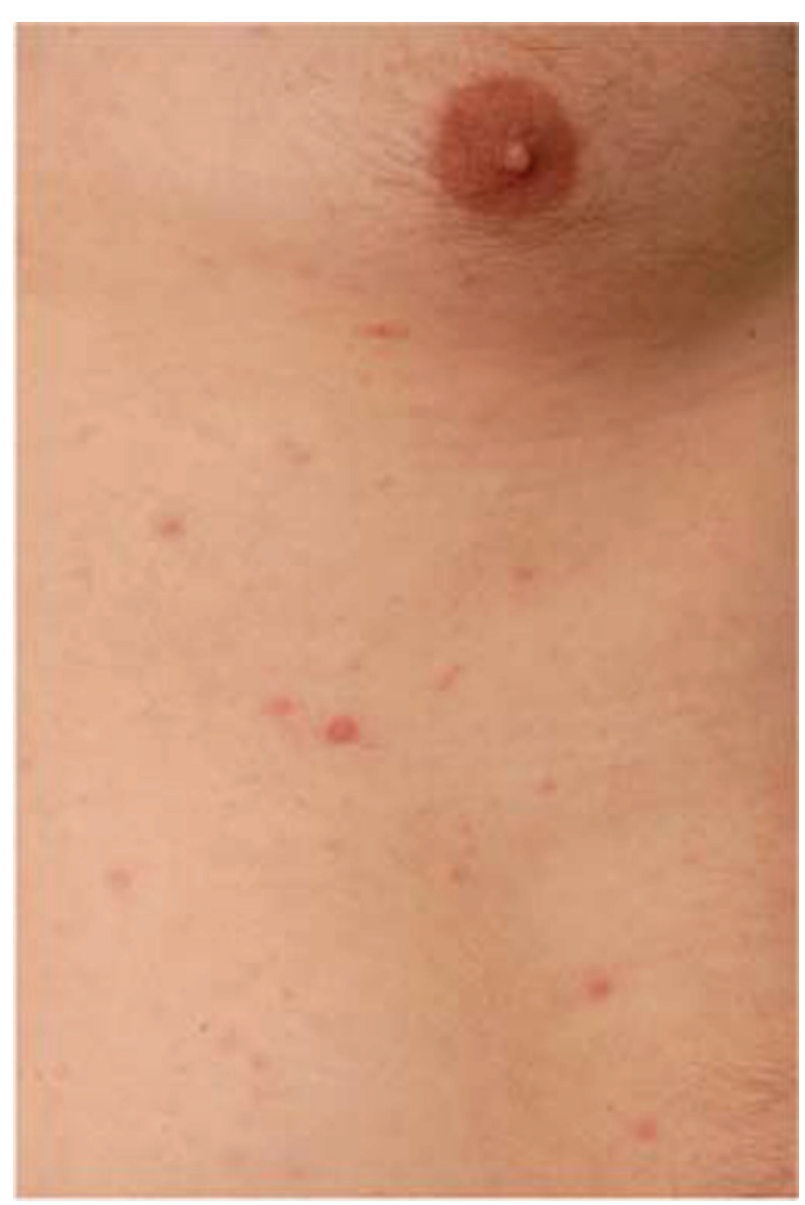

Figure 2 Papulonecrotic exanthema. 


\section{BMJ Case Reports}

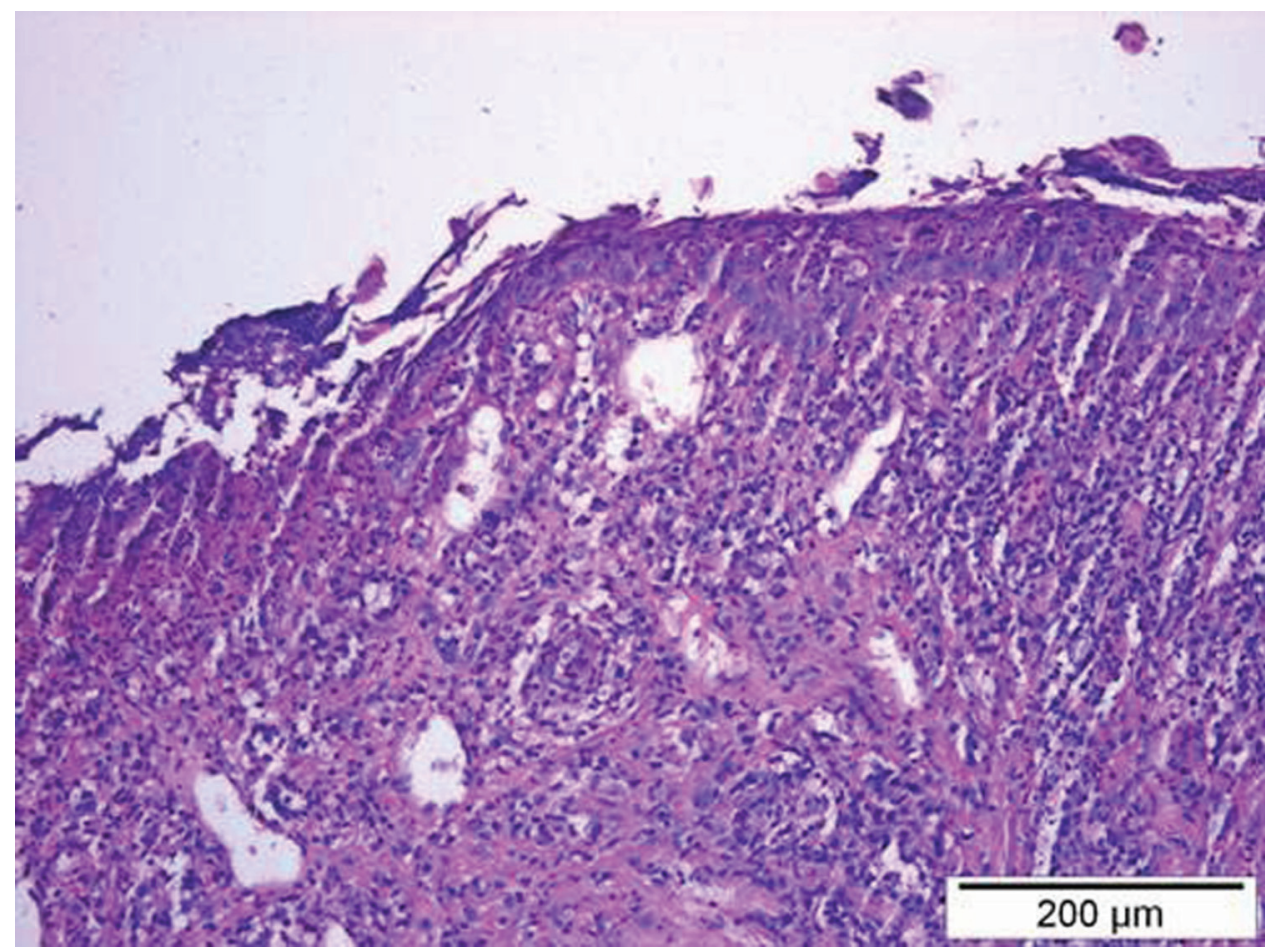

Figure 3 Deep epidermal defect with neutrophil infiltrate, H\&E staining.

to remind physicians to think about this diagnosis even in cases in which unsafe sexual contacts are denied and therefore sexually transmitted diseases seem to be ruled out.

\section{CASE PRESENTATION}

A 42-year-old man was suffering from swollen ankle joints, a disseminated exanthema of multiple, in part necrotic maculae and papules, intense headache and flu-like symptoms for 7 days. A 7-week history of painless ulcer on the penis, anus and scrotum was reported. Unsafe sexual contacts were strictly denied. The patient was admitted to the outpatient dermatology department with suspicion of Behcet's or Reiter's syndrome.

At the time of admission multiple, sharply circumscribed, centrally-ulcerated papules and erosions were localised on the penis, scrotum and anus and a generalised ulcerating maculopapulous exanthema involving soles and palms was found (figures 1 and 2). The size of single lesions reached up to $10 \mathrm{~mm}$ in diameter. Neither swollen lymph nodes nor hepatosplenomegaly was present.

\section{INVESTIGATIONS}

Serology showed active syphilis and HIV-1-infection (Treponema pallidum particle agglutination assay titre 1:3.338,240, fluorescent treponemal antibody -Abs positive, venereal disease research laboratory 1:256, HIV p24 antigen positive, HIV western blot positive with specific bands for HIV-1, HIV-RNA positive with 45000 copies/ $\mathrm{ml})$. Elevated cell count was detected in the cerebrospinal fluid without intrathecal antibody production. Further laboratory investigations showed elevated erythrocyte sedimentation rate, $\mathrm{C}$ reactive protein and liver enzymes. CD4-count was 528/ $\mathrm{ll}$, resulting in an HIV clinical stage IA according to center for disease control classification.
The skin biopsy specimen for histological examination was fixed in $4 \%$ neutral buffered saline, processed routinely, and embedded in paraffin. The tissue was pretreated with heat-induced epitope retrieval solution (Dako Cytomation target retrieval solution, pH 6.0; Dako Cytomation, Glostrup, Denmark) and incubated with a rabbit polyclonal antibody against spirochete infected tissue (Zytomed Systems, Berlin, Germany) in a dilution of 1:100. Stainings were performed using the Dako instrument Autostainer Plus and stained with the Dako REAL detection system alkaline phosphatase/red-conjugated anti-rabbit anti-mouse antibody (K5005). Sections were examined by light microscopy and showed an acanthotic broadened epidermis with spongiform infiltration of neutrophil leukocytes adjacent to a deep epidermal defect (figure 3). Some plasma cells were present within the infiltrate. Immunohistochemical staining revealed T pallidum in the upper part of the ulceration and in the subepidermal part of the ulcer margin (figure 4).

\section{DIFFERENTIAL DIAGNOSIS}

Differential diagnosis includes drug eruptions, presenting as maculopapulous exanthema, pityriasis lichenoides et varioliformis acuta, disseminated herpes or varizella zoster infections, ulcerating forms of vasculitis or pyoderma.

The results from histological examination in combination with serological investigation proved lues maligna and ruled out all differential diagnoses.

\section{TREATMENT}

The patient was treated with penicillin G 10 million IU intravenously three times daily for 21 days. Supportive single dose steroid treatment $(100 \mathrm{mg}$ prednisolone intravenous) was administered for prevention of JarischHerxheimer reaction. 


\section{BMJ Case Reports}

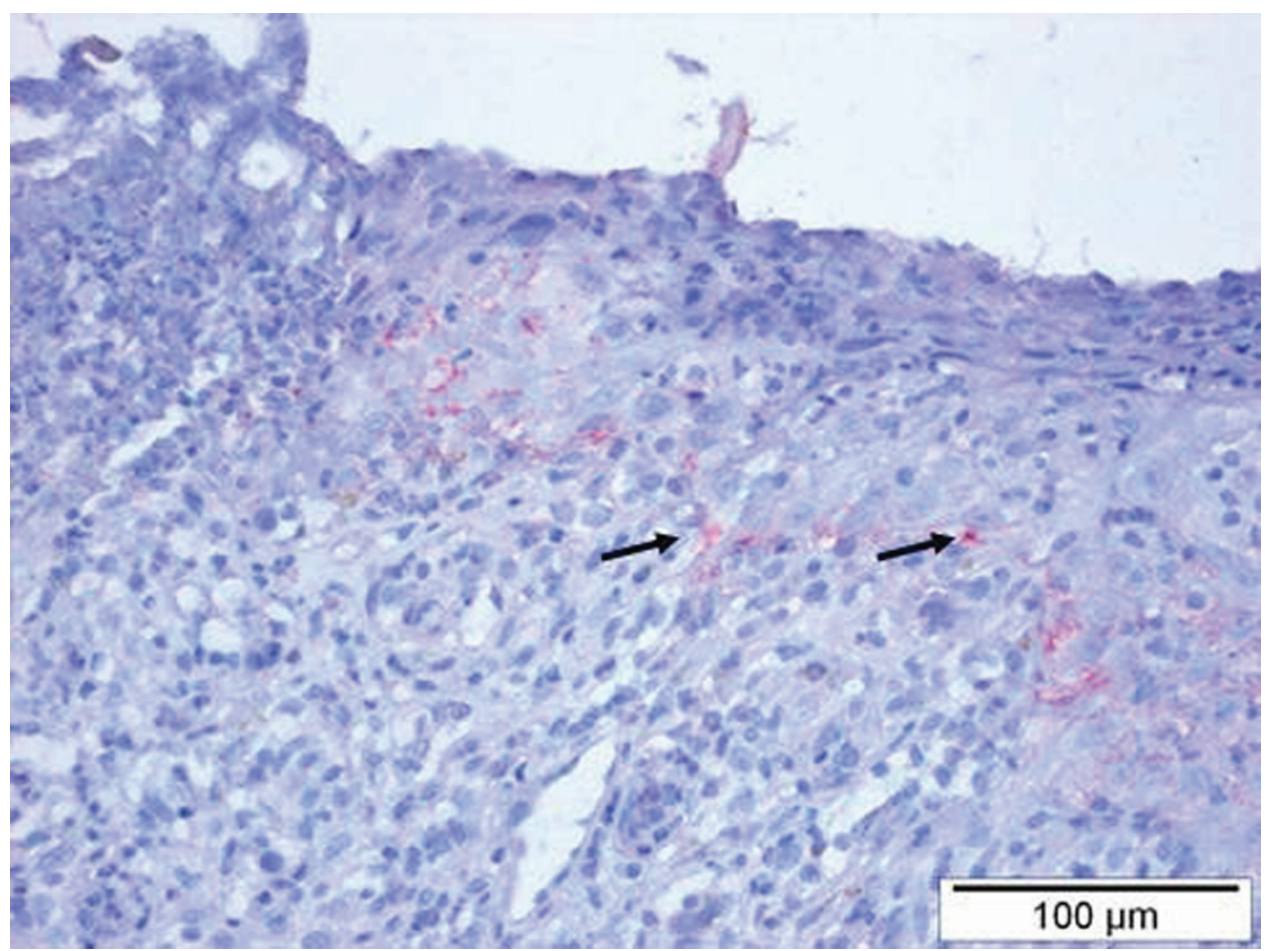

Figure 4 Staining of $T$ pallidum species with a specific antibody.

\section{OUTCOME AND FOLLOW-UP}

Flu-like symptoms and headache disappeared within 3 days, and skin lesions healed after 2 weeks.

\section{DISCUSSION}

Lues maligna (LM) is a rare manifestation of secondary syphilis, first and independently described in 1897 by Neisser ${ }^{1}$ and Haslund. ${ }^{2}$ LM is predominantly found in patients with immunodeficiency such as HIV or AIDS, but has also been reported in patients with chronic alcohol or drug abuse, tuberculosis or diabetes mellitus. ${ }^{3-6}$ LM may also present with ocular manifestations such as scleral nodules and keratitis or with leonine facies. ${ }^{7}$ Such symptoms were not present in our patient. In the decades before HIV and AIDS, the frequency of LM was very low (0.12-0.36\%) and until 1994 only about two dozen of cases with LM had been described in the English-language literature. ${ }^{3}$ Since then, the incidence of LM has been rising steadily according to an increase of lues in general..$^{8}$ Patients with LM usually show generalised swollen lymph nodes, whereas an involvement of internal organs is uncommon. About one half of all patients with LM show cerebrospinal fluid alterations but do not present neurological symptoms like the patient presented here. ${ }^{9}$ Intravenously applied penicillin G for 14-21 days, an effective treatment of LM, can be considered as state-of-the-art treatment for patients with LM and HIV or AIDS. ${ }^{8}$

In conclusion, secondary syphilis may present as LM especially in HIV-co-infected homosexual men and should therefore be included in the list of differential diagnoses in patients presenting with ulceronodular exanthema with or without ulcerous mucocutaneous lesions. Finally, one should be aware of the old dictum 'Omnis syphiliticus mendax (est)', that reflects that, the treating physician can never be sure that, the case history reported by the patient is in accordance with the facts, especially when concerning the patients sexual history. ${ }^{10}$

\section{Learning points}

- LM presents with an ulcerating exanthema, mostly accompanied by unspecific symptoms such as fever or painful joints

- $\mathrm{LM}$ as a rare form of secondary syphilis is mostly seen in homosexual men with HIV-coinfection

- Serological investigation should include further sexually transmitted diseases such as HIV or hepatitis $\mathrm{B} / \mathrm{C}$

- Lumbar puncture is essential, even in neurological asymptomatic patients

- Treatment with intravenously applied penicillin G should be preferred to intramuscular application.

\section{Competing interests None.}

Patient consent Obtained.

\section{REFERENCES}

1. Neisser A. Malignant syphilis. Br J Dermatol 1897;9:11-26.

2. Haslund A. Syphilis maligna. Archiv für Dermatologie und Syphilis 1897;38:345-92.

3. Sands $\mathbf{M}$, Markus A. Lues maligna, or ulceronodular syphilis, in a man infected with human immunodeficiency virus: case report and review. Clin Infect Dis 1995;20:387-90.

4. Bayramgürler D, Bilen N, Yildiz K, et al. Lues maligna in a chronic alcoholic patient. J Dermato/ 2005;32:217-19.

5. Hofmann UB, Hund M, Bröcker EB, et al.Lues maligna" in a female patient with diabetes. J Dtsch Dermatol Ges 2005;3:780-2.

6. Miltenburg C, Peters B, Coras B, et al. Glistening white erosions on the buccal mucosa with tonsillar edema more marked on the right than the left. $J$ Dtsch Dermatol Ges 2010;8:1021-3. 


\section{BMJ Case Reports}

7. De Socio GV, Simonetti S, Tomasini C, et al. Malignant syphilis with ocular involvement in an HIV-infected patient. Int J STD AIDS 2011:22:298-300.

8. Miltenburg C, Peters B, Coras B, et al. Glistening white erosions on the buccal mucosa with tonsillar edema more marked on the right than the left. $J$ Dtsch Dermatol Ges 2010:8:1021-3.
9. Bruch-Gerharz D, Lang K, Kruse R, et al. Necrotizing and vegetation syphilides - rare manifestations of secondary syphilis. Z Hautkr 2002; $77: 433-36$

10. Finger $\mathbf{E}$. Die Diagnose der syphilitischen Initialsclerose und der localen contagiösen Helcose. Arch Dermatol Res 1885;17:439-506.

This pdf has been created automatically from the final edited text and images.

Copyright 2011 BMJ Publishing Group. All rights reserved. For permission to reuse any of this content visit

http://group.bmj.com/group/rights-licensing/permissions.

BMJ Case Report Fellows may re-use this article for personal use and teaching without any further permission.

Please cite this article as follows (you will need to access the article online to obtain the date of publication).

Pföhler C, Koerner R, von Müller L, Vogt T, Müller CSL. Lues maligna in a patient with unknown HIV infection. BMJ Case Reports 2011; 10.1136/bcr.05.2011.4221, date of publication

Become a Fellow of BMJ Case Reports today and you can:

- Submit as many cases as you like

- Enjoy fast sympathetic peer review and rapid publication of accepted articles

- Access all the published articles

- Re-use any of the published material for personal use and teaching without further permission

For information on Institutional Fellowships contact consortiasales@bmjgroup.com

Visit casereports.bmi.com for more articles like this and to become a Fellow 